Original Research Paper

\title{
Benthic Macro-Invertebrate Survey in Little Beaver Creek, Kaw Lake Watershed
}

\author{
Dejene Alemayehu \\ Department of Kaw Nation Environmental, USA
}

Article history

Received: 30-10-2015

Revised: 23-12-2015

Accepted: 29-02-2016

Email: dejene@kawnation.com

\begin{abstract}
The Kaw Nation Environmental Department, as part of the water quality monitoring parameters in its non-point source pollution project conducted a benthic macro-inventebrat sampling and taxonomic classification as a stream bioassessment of Little Beaver and Bear Creeks. Little Beaver Creek is located in the tall grass prairie of Kay County, Oklahoma. It is one of the tributary creeks that enter Kaw Lake in the HUC 110060001. The macro-invertebrate samples were collected from three sites within Little Beaver Creek. The samples were collected in a net using a kick disturbance method referenced in U.S. EPA Rapid Bioassessment Protocol. A total of 10 orders and 46 taxa were identified. Taxa richness, EPT taxa richness, EPT abundance, Hilsenhoff Biotic Index and Shannon Weaver Diversity Index were calculated. It is the objective of this study to identify the chemical, physical and biological integrity of the water quality of the creeks and determine streams health as per the Clean Water Act stipulations. Based on the U.S. Environmental Protection Rapid Bioassessment protocol, the macro-invertebrate communities could be used as a tool to identify water quality and impaired streams as a result of non-point source pollution.
\end{abstract}

Keywords: Benthic Macro-Invertebrates, Water Quality, Macroinvertebrate, Stream BioAssessment

\section{Introduction}

The Kaw Nation is a federally recognized Native American tribe located in north central Kay County, OK. The Kaw Nation Environmental Department (KNED) as part of its water quality program collects macroinvertebrate sample from at least two creeks each year as a measure of the water quality parameters. Macroinvertebrates are indicative of the overall health of stream systems due to the tendency of the species to remain stationary within an area and their ability to respond quickly to stream conditions (Kenney et al., 2009). In 2009, KNED staff sampled Little Beaver Creek twice and Bear Creek once. These samples may tell KNED about the environmental health of the creeks.

The Clean Water Act stipulates that the chemical, physical and biological integrity waters are of high value. Most monitoring activities focused on chemical monitoring that alone has not lead to clean water in healthy streams (Karr and Chu, 1997). When biological integrity of a stream is considered as a criteria, the composition, diversity and functional organization of the habitat increases (Karr and Dudley, 1981; Karr et al., 1986). Macro-invertebrates studies can provide insight to the human impact upon streams and provides data where and when to protect streams from human influence. These studies may help us categorize the environmental health of the two creeks.

It is the objective of this study to describe the seasonal and spatial diversity of benthic macroinvertebrates in Little Beaver Creek.

\section{Materials and Methods}

Benthic invertebrate samples were collected as stream bioassessment from Little Beaver (star shape) and Bear Creeks (dot shape) in Kay County, Oklahoma as shown in Fig. 1. The study area, Little Beaver Creek, is located in the tall grass prairie region of Kay County, Oklahoma. It flows southerly entering Arkansas River at 12 miles. The site is within 11060001 Hydrological Unit Code. 


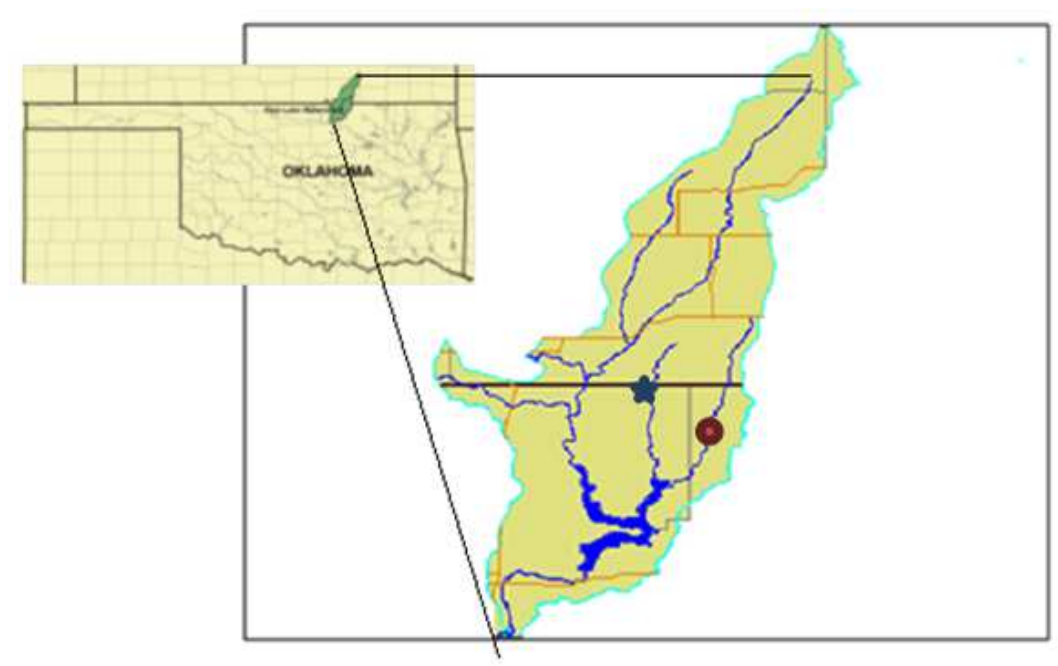

(a)

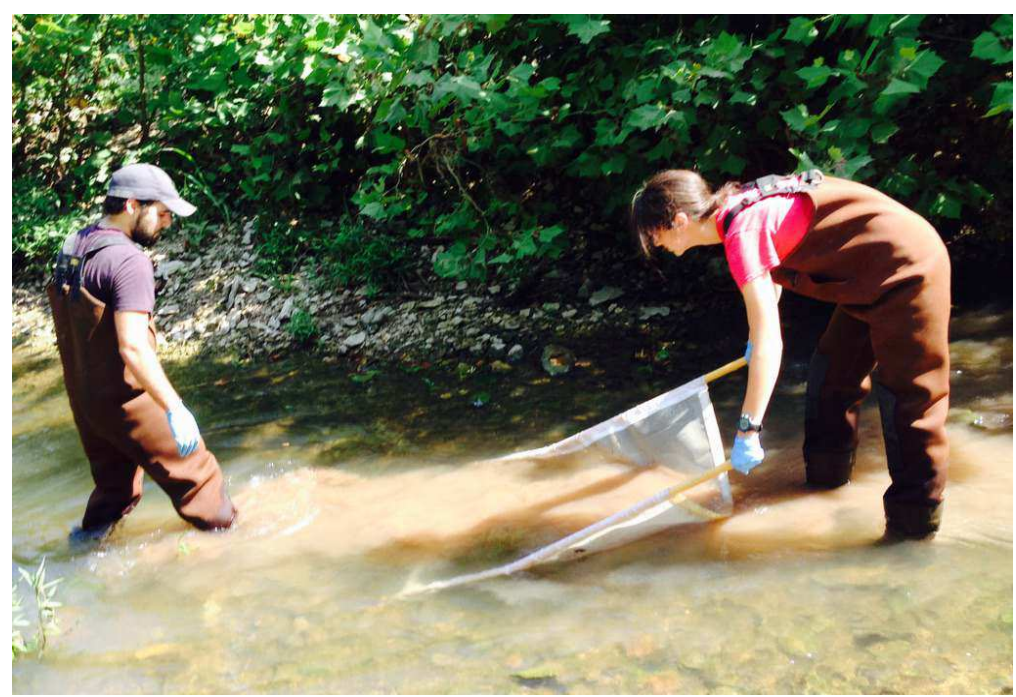

(b)

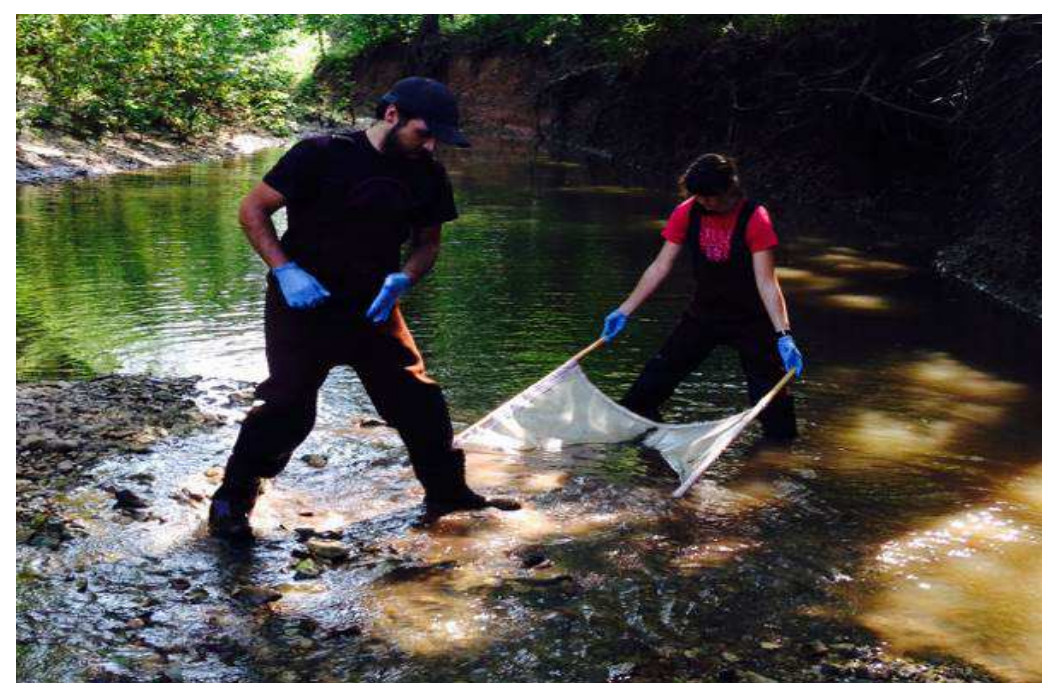

(c) 


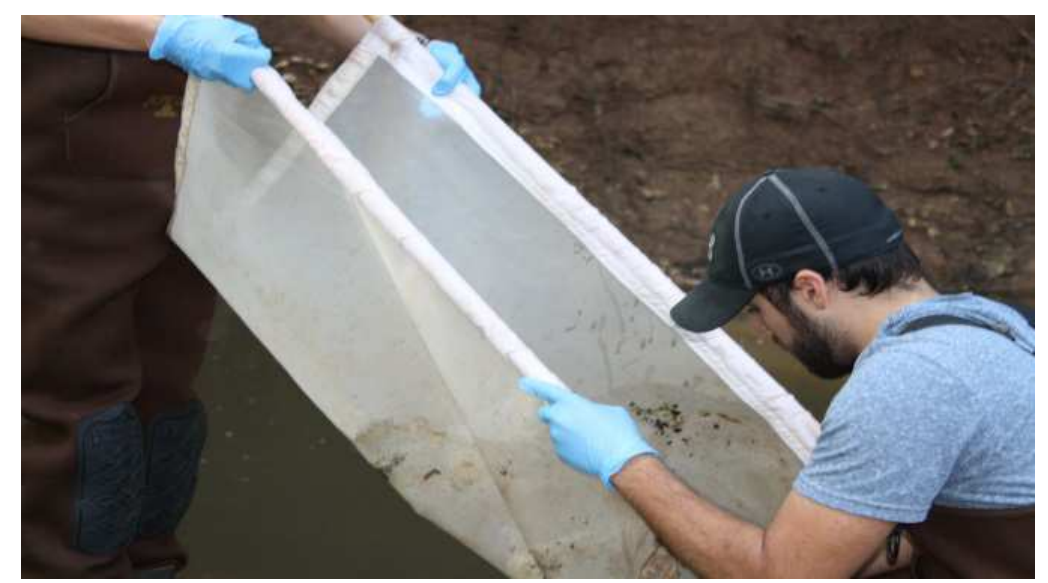

(d)

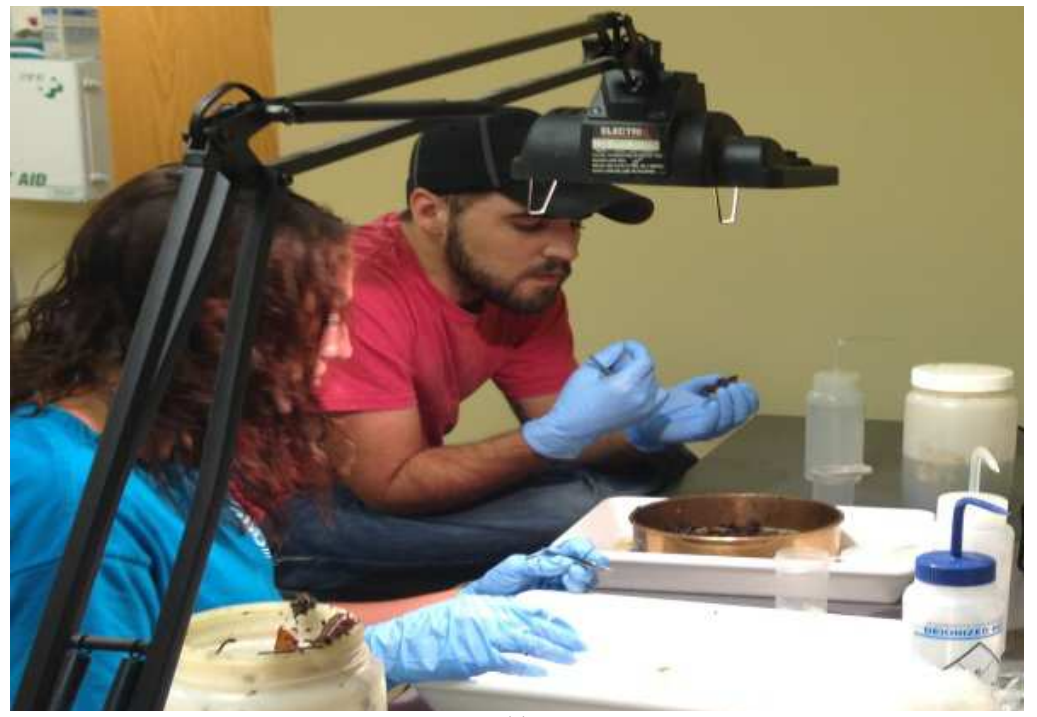

(e)

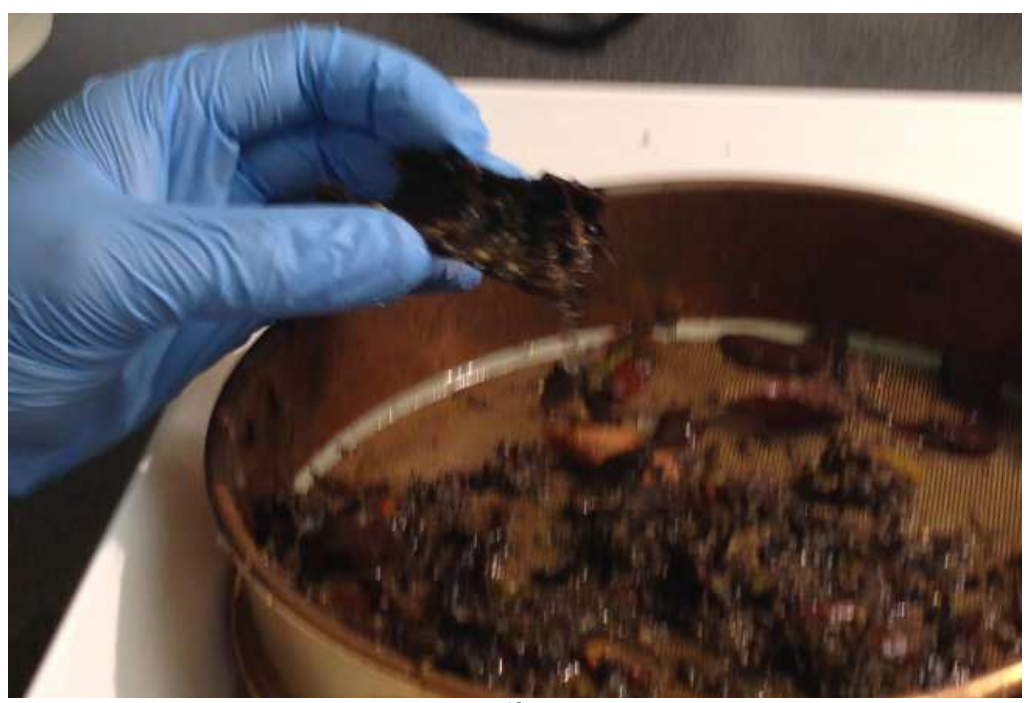

(f)

Fig. 1. (a) Kaw Lake Watershed; (b) Stirring up water before macro-invertebrate; (c) Kicking up sand before macro-invertebrate; (d) Picking macro-invertebrates out of net; (e) Sorting at KNED Lab; (f) Sorting at KNED Lab 
Kaw Nation Environmental Department staff collected two macro-invertebrate sample sites using a macro-invertebrate net and a kick disturbance method as detailed in the USEPA's Rapid Bio-assessment Protocols (Barbour et al., 1999).

The samples were collected from riffle sections of the creek. Before macro-invertebrate sampling, the water and sand in stirred up or kicked, so more macroinvertebrates will be captured in the net (Fig. $1 \mathrm{~b}$ and $1 \mathrm{c}$ ).

Macro-invertebrates were then picked out of the net and placed in $99 \%$ Isopropyl alcohol to euthanize and preserve them (Fig. 1d).

The samples were transported back to KNED's lab where they were sorted and identified to family level. Sorting at the KNED Lab was done using a white macro tray with a square inch divider (Fig. 1e and 1f).

The sorted samples were then sent to the Ecotoxicology and Water Quality Research Laboratory at Oklahoma State University in Stillwater, OK. This laboratory further identified the macro-invertebrate samples to the genus and species level and reported to KNED. The Index of Biotic Integrity (IBI) was calculated using a five metric Family Level Scoring Criteria. KNED also took water quality samples from the creek sites at the same time when the macroinvertebrates samples were taken. Water samples are taken regularly as part of KNED's, Section 106 water quality monitoring program. Physical parameters, such as $\mathrm{pH}, \mathrm{DO}$ and Temperature, were measured using YSI 6600 probes. Chemical analyses of $\mathrm{N}, \mathrm{P}, \mathrm{SO}_{4}$ and other parameters were done in the KNED laboratory. Further chemical analyses were done at Accurate Laboratory, an EPA certified lab in Stillwater, OK.

\section{Results}

The results generated by the OSU Laboratory were used to generate Table 1 and Fig. 2a-b. The OSU data and the Procedures in the Stream Keeper's Field Guide were used to calculate the Family Biotic Index (FBI), EPT/Midge Ratio, Taxa Richness, EPT Taxa Richness, EPT Abundance, Hilsenhoff Biotic Index (HBI), EPT/EPT + Chrionomids, Contribution of Dominant Taxon and the Shannon-Weaver Diversity (Murdoch et al., 1996).

Abundance and richness of assemblages or communities are simple measures and are often used in assessments; species-poor systems are generally assumed to have degraded water quality (Norris and Georges, 1993). Certain taxa such as stoneflies (Plecoptera), are known to be more sensitive to pollutants (DeWalt et al., 2005) and their presence is often considered an indicator of a healthy stream. Groupings of sensitive taxa such as the presence of EPT, which measures the proportion of individuals in the orders Ephemeroptera (mayflies), Plecoptera (stoneflies) and Tricoptera (caddisflies) are also used as an indicator of a healthy stream (Barbour et al., 1999).

\section{Water Quality}

The physical and chemical parameters of the water were recorded at the same time as the macro-invertebrate samples. Those results are shown here in Table 2 and 3.

Table 1. Macro-invertebrate calculations

\begin{tabular}{lcr}
\hline & Little beaver creek & Bear creek \\
& $6 / 09 / 2010$ & $6 / 09 / 2010$ \\
\hline Total Taxa/rep & 10.00 & 4.000 \\
Total Taxa/site & & 4.000 \\
\#EPT* & 5.00 & 1.000 \\
\%EPT & 68.10 & 1.600 \\
Abundance & 116.00 & 62.000 \\
Diversity & 1.77 & 0.479 \\
Average Diversity & & \\
(Standard Deviation) & & 0.480 \\
Family Biotic Index & 2.78 & 6.000 \\
EPT/Midge Ratio & 1.25 & 1.000 \\
Shannon-Weaver Index & 1.80 & 0.480 \\
Hilsenhoff Biotic Index & 2.10 & 125.400 \\
5 Metric Family Level IBI & 32.00 & 22.000 \\
\hline
\end{tabular}

Table 2. Physical parameters (06/09/2010)

\begin{tabular}{lccl}
\hline & Little beaver & Bear creek & Unit of measurement \\
\hline Temperature & 23.40 & 24.14 & deg C \\
Specific conductance & 423.00 & 275.00 & $\mu \mathrm{S} / \mathrm{cm}$ \\
Dissolved oxygen & 13.64 & 12.77 & $\mathrm{mg} / \mathrm{l}$ \\
$\mathrm{pH}$ & 8.04 & 8.13 & $\mathrm{NTU}$ \\
Turbidity & 15.30 & 59.00 & $\mu \mathrm{g} / \mathrm{l}$ \\
Chlorophyll $\alpha$ & 3.70 & 12.10 & \\
\hline
\end{tabular}


Table 3. Chemical parameters $(06 / 09 / 2010)$

\begin{tabular}{|c|c|c|c|}
\hline & Little beaver creek & Bear creek & Unit of measurement \\
\hline Alkalinity, bicarbonate & 221 & 152 & $\mathrm{mg} / \mathrm{l}$ \\
\hline Alkalinity, carbonate & BPQL & BPQL & $\mathrm{mg} / \mathrm{l}$ \\
\hline Chloride & 1.88 & 2.97 & $\mathrm{mg} / \mathrm{l}$ \\
\hline Chlorophyll a & 2.7 & 6.4 & $\mathrm{mg} / \mathrm{m}^{3}$ \\
\hline Fecal Coliform & 310 & 360 & $\mathrm{cfu} / 100 \mathrm{~mL}$ \\
\hline Escherichia coli & 387 & 248 & MPN/100 mL \\
\hline Enterococcus & 150 & 113 & MPN/100 mL \\
\hline Phosphorus as $\mathrm{P}$ & BPQL & 0.11 & $\mathrm{mg} / \mathrm{l}$ \\
\hline Ammonia & BPQL & BPQL & $\mathrm{mg} / \mathrm{l}$ \\
\hline Nitrite & BPQL & BPQL & $\mathrm{mg} / \mathrm{l}$ \\
\hline Nitrate & 0.6 & 0.52 & $\mathrm{mg} / \mathrm{l}$ \\
\hline Kjeldahl nitrogen & BPQL & BPQL & $\mathrm{mg} / \mathrm{l}$ \\
\hline Aluminum & 1.16 & 2.47 & $\mathrm{mg} / \mathrm{l}$ \\
\hline Arsenic & BPQL & BPQL & $\mathrm{mg} / \mathrm{l}$ \\
\hline Barium & 0.126 & 0.101 & $\mathrm{mg} / \mathrm{l}$ \\
\hline Beryllium & BPQL & BPQL & $\mathrm{mg} / \mathrm{l}$ \\
\hline Cadmium & BPQL & BPQL & $\mathrm{mg} / \mathrm{l}$ \\
\hline Calcium & 74.5 & 48.9 & $\mathrm{mg} / \mathrm{l}$ \\
\hline Chromium & BPQL & BPQL & $\mathrm{mg} / \mathrm{l}$ \\
\hline Cobalt & BPQL & BPQL & $\mathrm{mg} / \mathrm{l}$ \\
\hline Copper & BPQL & BPQL & $\mathrm{mg} / \mathrm{l}$ \\
\hline Iron & 0.88 & 1.74 & $\mathrm{mg} / \mathrm{l}$ \\
\hline Magnesium & 6.4 & 5.72 & $\mathrm{mg} / \mathrm{l}$ \\
\hline Manganese & 0.039 & 0.073 & $\mathrm{mg} / \mathrm{l}$ \\
\hline Mercury & BPQL & BPQL & $\mathrm{mg} / \mathrm{l}$ \\
\hline Nickel & BPQL & BPQL & $\mathrm{mg} / \mathrm{l}$ \\
\hline Potassium & 2.18 & 3.52 & $\mathrm{mg} / \mathrm{l}$ \\
\hline Selenium & BPQL & BPQL & $\mathrm{mg} / \mathrm{l}$ \\
\hline Sodium & 5 & 7.87 & $\mathrm{mg} / \mathrm{l}$ \\
\hline Zinc & 0.005 & 0.005 & $\mathrm{mg} / \mathrm{l}$ \\
\hline Triazine mixture, unspecified & BPQL & BPQL & ug/l \\
\hline
\end{tabular}

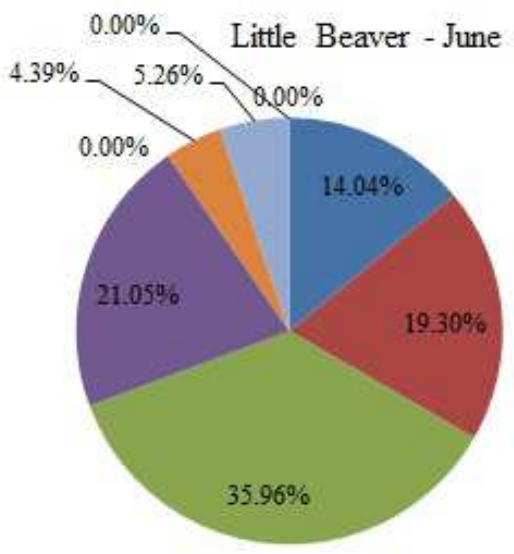

(a)

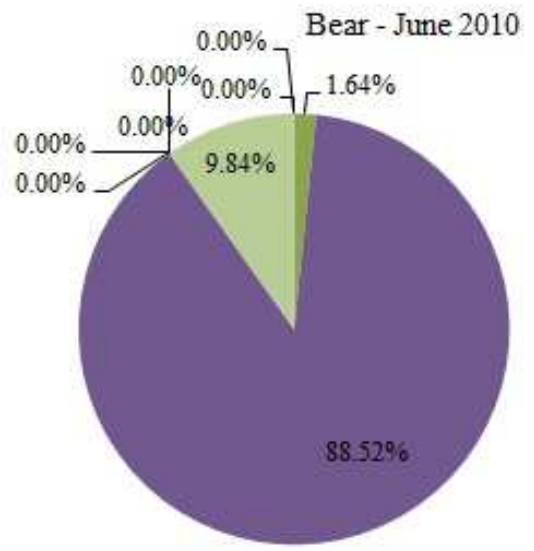

Ephem eroptera

- Plecoptora

- Trichopiera

- Diptera

Oodonata

Coleoptera

- Megaloptera

- Hemiptera

Decapoda

Fig. 2. (a) Little beaver Creek Class percentages; (b) Bear class percentages

\section{Discussion}

Ten different invertebrate taxa were identified from Little Beaver Creek while only 4 different taxa were identified from Bear Creek. Trichoptera (Cheumatopsyche) were the most abundant genus on macro-invertebrate in Little Beaver Creek in June, 2010.
At Bear Creek Diptera (Chironomidae) were most abundant. All the indexes above show Little Beaver Creek is of better quality than Bear Creek in terms of water quality and species diversity. In Table 1, the average macro-invertebrate diversity, Ephemeroptera, Plecoptera and Trichoptera (EPT) and total abundance were higher at Little Beaver Creek than Bear Creek. 
Table 4. Evolution of water quality using the family biotic index (Hilsenhoff, 1988)

\begin{tabular}{lll}
\hline Family Biotic Index & Water quality & Degree of organic pollution \\
\hline $0.00-3.75$ & Excellent & Organic pollution unlikely \\
$3.76-4.25$ & Very good & Possible slight organic pollution \\
$4.26-5.00$ & Good & Some organic pollution probable \\
$5.01-5.75$ & Fair & Fairly substantial pollution likely \\
$5.76-6.50$ & Fairly poor & Substantial pollution likely \\
$6.51-7.25$ & Poor & Very substantial pollution likely \\
$7.26-10.00$ & Very poor & Severe organic pollution likely \\
\hline
\end{tabular}

Table 1 data reflects the condition of Bear Creek being poorer than Little Beaver Creek. The FBI indicated that Bear Creek is in fairly poor condition and Little Beaver Creek was in good condition in June according to the classification described below by Hilsenhoff (1988) in Table 4.

Non-point source pollution is the major source of impairment for both Little Beaver Creek and Bear Creek. However, there is less buffer zone present along Bear Creek. Bear Creek is also much more influenced by Kaw Lake's water level. The lake backs up all the way up to Bear Creek several times per year. At dry times Bear Creek dries fast to the point of having no flow. The combination of both of these conditions greatly reduces the amount of permanent habitat available for macro-invertebrates.

\section{Conclusion}

The water quality data that was collected at the time of macro-invertebrate sampling showed over all good water quality. Turbidity of the sites matched up to that of the biotic indexes calculated from the macro-invertebrate data. Bear Creek had the highest turbidity and the lowest biotic index both indicating poor environmental health due to runoff coming to the creeks from various farm lands within the watershed called non-point source pollution.

Bear Creek was lower in bacteria than Little Beaver Creek due to the volume of lake water that serves to dilute concentrations. Human activities such as cattle ranching and the building of the Kaw Dam have affected Bear Creek. A decrease in the abundance of individual species or genera could be attributed to riparian deforestation. A decrease in the riparian vegetation would contributed to an increase in nutrients or litter inputs, altered water temperature, decreased bed stability and increase in sedimentation making Bear Creek more impaired than Little Beaver Creek.

The hypothesis that Little Beaver Creek is in better environmental health than Bear Creek was verified by this macro-invertebrate sampling and that Bear Creek is more impaired than Little Beaver Creek due to the nonpoint source pollution.

In general, macro-invertebrate can be used as biological indicators to determine whether a stream has good or bad water quality. The abundance and species richness determines stream health. The higher percentage of Ephemeroptera, Plecoptera and Trichoptera (EPT) in a stream like Little Beaver Creek exhibits better water quality.

\section{Acknowledgment}

The author would like to thank the U.S. Environmental Protection Agency Region 6 for funding this study. We would also like to thank Mr. Sammuel Reynolds for his technical advise and approval of the research. Thanks goes to Ms. Elaine Huch for her permission to let us carry out this research. Special thanks also goes to Ms. Francine Hackett, Kaw Nation IT Specialist for editing and developing the tables and charts.

\section{Funding Information}

Financial support for this study was provided by U.S. Environmental Protection Agency, Region 6, Dallas, Texas.

\section{References}

Barbour, M.T., J. Gerritsen, B.D. Snyder and J.B. Stribling, 1999. Rapid Bioassessment Protocols for Use in Streams and Wadeable Rivers: Periphyton, Benthic Macro-invertebrates and Fish. 2nd Edn., U.S. Environmental Protection Agency, Office of Water, Washington, D.C.

DeWalt, R.E., C. Favret and D.W. Webb, 2005. Just how imperiled are aquatic insects? A case study of stoneflies (Plecoptera) in Illinois. Annals Entomol. Society Am., 98: 941-950. DOI: 10.1603/00138746(2005)098[0941:JHIAAI]2.0.CO;2

Hilsenhoff, W.L., 1988. Rapid field assessment of organic pollution with a family-level biotic index. J. North Am. Benthol. Society, 7: 65-68. DOI: $10.2307 / 1467832$

Karr, J.R. and E.W. Chu, 1997. Biological Monitoring and Assessment: Using Multimetric Indexes Effectively. 1st Edn., University of Washington, Seattle, pp: 149.

Karr, J.R. and D.R. Dudley, 1981. Ecological perspective on water quality goals. Environ. Manage., 5: 55-68. DOI: 10.1007/BF01866609 
Karr, J.R., K.D. Fausch, P.L. Angermeier, P.R. Yant and I.J. Schlosser, 1986. Assessing Biological Integrity in Running Waters: A Method and its Rationale. 1st Edn., Illinois Natural History Survey, Special Publication, pp: 28.

Kenney, M.A., A.E. Sutton-Grier, R.F. Smith and S.E. Gresens, 2009. Benthic macro-invertebrates as indicators of water quality: The intersection of science and policy. Terrestrial Arthropod Rev., 2: 99-128. DOI: $10.1163 / 187498209 X 12525675906077$
Murdoch, T., M. Cheo and K. O'Laughlin, 1996. The StreamKeeper's Field Guide: Watershed Inventory and Stream Monitoring Methods. 5th Edn., AdoptA-Stream Foundation, Everett, ISBN-10: 0965210901, pp: 296.

Norris, R.H. and A. Georges, 1993. Analysis and Interpretation of Benthic Macro-invertebrate Surveys. In: Freshwater Biomonitoring and Benthic Macroinvertebrates, Rosenberg, D.M. and V.H. Resh (Eds.), Chapman and Hall, New York, pp: 234-286. 